\title{
Evaluation of Trace Elements in Malay Women with Type 2 Diabetes Mellitus
}

(Penilaian terhadap Unsur Surih dalam Kalangan Wanita Melayu dengan Diabetes Melitus Jenis 2)

\author{
MOHAMMED NASHIRY, ISMARULYUSDA ISHAK*, JAMALUdIN MOHAMED, SiTI BALKIS BUdIN, \\ MOHD FAIRULNIZAL M.N., SAZLINA KAMARALZAMAN \& HESHAM M. Al-MEKHLAFI
}

\begin{abstract}
Trace elements are essential for human health. This study determines the level of chromium (Cr), zinc (Zn), selenium $(\mathrm{Se})$, copper $(\mathrm{Cu})$, ferrum $(\mathrm{Fe})$ and manganese $(\mathrm{Mn})$ in the hair and nails of married Malay women with type 2 diabetes mellitus from Hulu Langat, Selangor, Malaysia. The trace elements were analysed using inductively coupled plasma mass spectrometry (ICP-MS) after an acid digestion treatment. The levels of all trace elements measured were higher in the hair samples than in nails except for Se. Mean levels of Zn and Se were significantly higher in the hair of non-working women $(84.91 \pm 10.32 \mu \mathrm{g} / \mathrm{g}$ and $0.42 \pm 0.15 \mu \mathrm{g} / \mathrm{g}$, respectively) compared to working women $(64.98 \pm 11.10 \mu \mathrm{g} / \mathrm{g}$ and $0.30 \pm 0.18 \mu \mathrm{g} / \mathrm{g})$. Copper levels in hair were significantly higher among women with good and satisfactory diabetes control $(20.41 \pm 4.20 \mu \mathrm{g} / \mathrm{g})$ compared to the poor diabetes control group $(15.67 \pm 4.31 \mu \mathrm{g} / \mathrm{g})$. However, a contradictory result was obtained from the nails of women with good and satisfactory diabetes control with a Cu level of $3.35 \pm 0.46$ $\mu \mathrm{g} / \mathrm{g}$ and $4.69 \pm 0.33 \mu \mathrm{g} / \mathrm{g}$ for the poor diabetes control group. In hair samples, significant positive correlations were obtained with $\mathrm{Cr}-\mathrm{Cu}(r=0.55), \mathrm{Zn}-\mathrm{Mn}(r=0.46)$ and $\mathrm{Se}-\mathrm{Mn}(r=0.38)$. In nails, significant positive correlations were also obtained between $\mathrm{Cr}-\mathrm{Zn}(r=0.31), \mathrm{Zn}-\mathrm{Fe}(r=0.30)$ and $\mathrm{Fe}-\mathrm{Mn}(r=0.47)$. In conclusion, age, educational status, number of children and duration of diabetes did not influence trace elements levels.
\end{abstract}

Keywords: Diabetes mellitus; female; HbAlc; ICP-MS; trace elements

\section{ABSTRAK}

Unsur surih adalah penting untuk kesihatan manusia. Kajian ini akan menentukan tahap kromium, zink (Zn), selenium (Se), kuprum ( $\mathrm{Cu}$ ), ferum ( $\mathrm{Fe}$ ) dan mangan ( $\mathrm{Mn}$ ) dalam rambut dan kuku wanita Melayu yang sudah berkahwin dengan diabetes melitus jenis 2 dari Hulu Langat, Selangor, Malaysia. Unsur surih telah dianalisis dengan menggunakan spektrometri jisim plasma gandingan aruhan (ICP-MS) selepas rawatan asid penghadaman. Tahap semua unsur surih yang diukur adalah lebih tinggi dalam sampel rambut daripada kuku kecuali Se. Tahap min Zn dan Se adalah jauh lebih tinggi dalam rambut wanita tidak bekerja (masing-masing $84.91 \pm 10.32 \mu \mathrm{g} / \mathrm{g}$ dan $0.42 \pm 0.15 \mu \mathrm{g} / \mathrm{g}$,) berbanding wanita bekerja $(64.98 \pm 11.10 \mu \mathrm{g} / \mathrm{g}$ dan $0.30 \pm 0.18 \mu \mathrm{g} / \mathrm{g})$. Tahap kuprum dalam rambut adalah jauh lebih tinggi dalam kalangan wanita dengan kawalan diabetes yang baik dan memuaskan $(20.41 \pm 4.20 \mu \mathrm{g} / \mathrm{g})$ berbanding dengan kumpulan kawalan diabetes melitus yang tidak dikawal $(15.67 \pm 4.31 \mu \mathrm{g} / \mathrm{g})$. Walau bagaimanapun, keputusan bercanggah telah diperoleh daripada kuku wanita dengan kawalan diabetes yang baik dan memuaskan dengan tahap Cu ialah $3.35 \pm 0.46$ $\mu \mathrm{g} / \mathrm{g}$ dan $4.69 \pm 0.33 \mu \mathrm{g} / \mathrm{g}$ bagi kumpulan kawalan diabetes melitus yang tidak dikawal. Pada sampel rambut, korelasi positif yang signifikan diperoleh dengan $\mathrm{Cr}-\mathrm{Cu}(r=0.55), \mathrm{Zn}-\mathrm{Mn}(r=0.46)$ dan Se-Mn $(r=0.38)$. Pada kuku, korelasi positif yang signifikan juga diperoleh antara Cr-Zn $(r=0.31), \mathrm{Zn}-\mathrm{Fe}(r=0,30)$ dan Fe-Mn $(r=0.47)$. Kesimpulannya, umur, tahap pendidikan, bilangan anak dan tempoh diabetes tidak mempengaruhi tahap unsur surih.

Kata kunci: Diabetes melitus; HbAlc; ICP-MS; perempuan; unsur surih

\section{INTRODUCTION}

Diabetes mellitus (DM) is a disorder of multiple etiologies characterised by chronic hyperglycemia with disturbances of the carbohydrate, fat and protein metabolism resulting from defects in insulin secretion (type $1 \mathrm{DM}$ ) or action (type 2 DM). The prevalence of diabetes is increasing globally with the most rapid increases occurring in developing countries including the Asian region and among younger age groups (Rhee 2015). These increasing prevalence rates have been found to be associated with urbanisation which is associated with sedentary lifestyles, ageing and unhealthy diets. According to the World Health Organisation, the number of people with diabetes has risen from 108 million in 1980 to 422 million in 2014 (WHO 2016). The Fifth National Health and Morbidity Survey (2015), showed that the overall prevalence of DM among Malaysians was $17.5 \%$. DM was found to be associated with increasing age, positive family history of DM, obesity, and lower levels of education (Fifth National Health and Morbidity Survey 2015; Rampal et al. 2010).

Interest in trace elements has been increasing steadily over the last few decades. Trace elements are 
essential for optimum human health due to their diverse metabolic characteristics and functions. Furthermore, these elements are involved in glucose homeostasis and metabolism. Moreover, previous studies have shown that the metabolism of several trace elements is altered in DM, suggesting specific roles for trace elements in the pathogenesis and progress of this disease (Flores et al. 2011; Khalid et al. 2014). At a cellular level, chromium maintains insulin receptors, enhances insulin sensitivity and improves insulin action in moving glucose into the cells (Unjiati et al. 2015). A recent report found that newly diagnosed diabetes patients have chromium levels lower than non-diabetes individuals (Unjiati et al. 2015).

Preclinical investigations showed that zinc supplementation has insulin-enhancing effects, improves $\beta$-cell function and lowers blood glucose (Wolfgang 2017). The antioxidant functions of selenium are attracting more researchers due to its important association with DM (De Vega et al. 2016). Selenium deficiency was observed in the association with many illnesses including some types of cancer, heart disease and DM. (Rayman 2000). A metaanalysis has reported that levels of copper in DM patients are higher than healthy people (Qiu et al. 2017).

Additionally, an imbalance of copper and other transition metals contribute to the generation of advanced glycation end products (AGES) and reactive oxygen species (ROS) (Lowe et al. 2017). Previous studies reported that high levels of iron $(\mathrm{Fe})$ contributed to the incidence of type $2 \mathrm{DM}$ and associated with insulin resistance (Altamura et al. 2017). Also, Mn supplementation improved manganese superoxide dismutase (MnSOD) activity and showed protection against complication of type 2 DM (Burlet \& Jain 2013; Lee et al. 2013).

In Malaysia, little is known about the status of trace elements among diabetic patients. Thus, this study evaluates trace elements among Malay women with type 2 DM. Six essential elements were studied: chromium, zinc, copper, iron, manganese and selenium from scalp hair and fingernails specimens. The status of these elements was compared between subjects according to their sociodemographic data and status of diabetes control.

\section{MATERIALS AND METHODS}

\section{STUDY DESIGN AND SUBJECTS}

A cross-sectional study was carried out among 39 Malay women with type 2 diabetes in the Hulu Langat district of Selangor state, Malaysia (2009-2010). The following criteria were used to select the subjects: Malay women aged between 20 and 60 years and diagnosed with type 2 DM, while exclusion criteria included suffering chronic or terminal illness such as heart disease, cancer and kidney disease, psychiatric illness with ongoing medication, type $1 \mathrm{DM}$, pregnancy or two months post-partum and having stained hair and/or nails. Informed consent was sought and obtained from subjects before recruitment into the study.
Subjects' samples were collected at Universiti Kebangsaan Malaysia.

\section{QUESTIONNAIRE}

A pre-tested questionnaire and face-to-face interviews were used to collect data on the socio-demographic status, health status and the medical history of the subjects. The first section of the questionnaire was related to respondents' demographic data which include name, address and contact, identity card number, date of birth, age and family income. The second section was related to the history of diabetes, health status and the drugs and supplements used by the subjects.

\section{SAMPLES COLLECTION}

A sample of nails was collected from each participants using a stainless-steel clipper. About three to five strands of scalp hair (occipital area) were collected and stored in a closed plastic bag at room temperature until the time of analysis. Three $\mathrm{mL}$ of blood were collected in ethylenediaminetetraacetic acid (EDTA) tubes and sent to a private laboratory for haemoglobin $\mathrm{A} 1 \mathrm{c}(\mathrm{HbA} 1 \mathrm{c})$ estimation.

\section{SAMPLE WASHING}

Hair and nail samples were washed according to the methods of Batista et al. (2008) and Miekeley et al. (1998). The washing procedures were performed in an ultrasonic bath (model-5510, Branson Ultrasonic Corp, USA). First, the samples were washed with $20 \mathrm{~mL}$ of acetone (ultrapure) for $10 \mathrm{~min}$. After three short rinses with water to remove the organic solvent, the samples were washed three times for $10 \mathrm{~min}$ each with $20 \mathrm{~mL}$ of $1 \%$ Triton $\mathrm{X}-100^{\circledR}$. The detergent types and washing times are chosen to ensure the maximum cleaning of external contamination to avoid loss of endogenous elements. The samples were rinsed with Milli-Q water to remove the detergent and then the samples were dried in an oven at $60^{\circ} \mathrm{C}$ for overnight.

\section{SAMPLE DISSOLUTION AND PREPARATION}

Samples digestion was performed according to the method of Miekeley et al. (1998) with little modification due to low sample weight. Hair or nail samples were wet washed with $0.5 \mathrm{~mL}$ of $\mathrm{HNO} 3$ (p.a. grade) in a closed graduated polypropylene tube $(15 \mathrm{~mL})$ overnight at room temperature. Then, the samples were incubated for $1 \mathrm{~h}$ at $60-70^{\circ} \mathrm{C}$ in a drying oven. After cooling, $0.2 \mathrm{~mL} \mathrm{H} 2 \mathrm{O} 2$ $(30 \% \mathrm{v} / \mathrm{v})$ was added, and the samples were incubated again for $1 \mathrm{~h}$ at $70^{\circ} \mathrm{C}$. After that, the samples were diluted to a final volume of $10 \mathrm{~mL}$ with Milli-Q water $18.2 \mathrm{M} \Omega-\mathrm{cm}$.

\section{PREPARATION OF BLANK}

Blank was prepared in a $25 \mathrm{~mL}$ volumetric flask by adding $0.5 \mathrm{~mL}$ of $65 \% \mathrm{HNO} 3$ and $0.2 \mathrm{~mL} \mathrm{H} 2 \mathrm{O} 2$. Then, the volume was made up to $10 \mathrm{~mL}$ with Milli-Q water at $18.2 \mathrm{M} \Omega-\mathrm{cm}$. This volume was transferred to a $15 \mathrm{~mL}$ closed graduated 
polypropylene tube.

\section{ICP-MS CALIBRATION AND SAMPLE ANALYSIS}

Calibration was performed by preparing six serial concentrations for the multi-element standard solution $2,8,20,50,100$, and $250 \mu \mathrm{g} / \mathrm{L}$ and a calibration graph was plotted. Sample standard and blank were analysed using inductively coupled plasma mass spectrometry (ICPMS, Perkin Elmer Sciex Elan 9000, USA). All glass and plastic wares such as tubes, volumetric flasks, cylinder and pipettes, tips and containers were cleaned before use according to Talbot and Weiss (1994). These items were soaked with an analytical grade nitric acid solution and ultrapure water overnight and then rinsed three times with Milli-Q water. After that, all the glass and plastic wares were dried in a clean oven and kept in a closed container to prevent contamination. Table 1 lists the equipment and operating conditions used in this study.

\section{STATISTICAL ANALYSIS}

TABLE 1. Equipment and operating conditions used in this study

\begin{tabular}{ll}
\hline ICP-mass spectrometry & \\
\hline Instrument & Perkin Elmer Elan 9000 \\
RF-power & $1000 \mathrm{~W}$ \\
Plasma gas flow rate & $20 \mathrm{~L} / \mathrm{min}$ \\
Spray chamber & Ryton double pass \\
Cone & Nickel \\
Resolution & $0.7 \pm 0.1$ amu \\
Isotopes measured & $\mathrm{Cr}-52, \mathrm{Zn}-66, \mathrm{Se}-82$ \\
& $\mathrm{Cu}-63, \mathrm{Fe}-57, \mathrm{Mn}-55$ \\
Dwell time & 250 ms \\
Sweeps & 20 per reading \\
Replicate & Three \\
\hline
\end{tabular}

The Statistical Package for Social Sciences for Windows (SPSS version 18.0) was used for statistical analysis of the data. The normality of elements levels was examined using the Shapiro-Wilks test and was found to be normal. Pearson's correlation was used to test the correlation between elements, and t-test and/or ANOVA was used to compare the levels of the elements between groups whereby $p<0.05$ was considered statistically significant.

\section{RESULTS}

Thirty-nine Malay women patients aged 25 to 60 years with a mean age of $43.95 \pm 8.7$ years and diagnosed for type 2 DM who had received treatment at three clinics in the Hulu Langat district of Selangor state, Malaysia, participated in this study. The basic characteristics of the subjects are shown in Table 2. All the subjects were married and about three-quarters of them showed poor diabetes control based on the measurement of glycated haemoglobin (HbA1c). The mean \pm S.D of HbAlc for poor control group was significantly higher than good control group at $10.49 \pm 1.97$ compared to $6.19 \pm 0.42(\mathrm{t}=-10.994, P<0.05)$.

TABLE 2. Basic characteristics of the subjects

\begin{tabular}{lcc}
\hline Variables & Frequency & Percentage $(\%)$ \\
\hline Age & & \\
$20-30$ & 4 & 10.3 \\
$31-40$ & 19 & 20.5 \\
$41-50$ & 8 & 48.7 \\
$51-60$ & & 20.5 \\
Education status & 8 & \\
$\quad$ Primary school & 21 & 20.5 \\
$\quad$ Secondary school & 9 & 53.8 \\
$\quad$ Diploma/STPM & & 23.1 \\
Employment status & 20 & \\
$\quad$ Working & 18 & 51.3 \\
$\quad$ Not working & & 46.2 \\
Number of children & 21 & \\
$\quad<4$ & 16 & 41.0 \\
$\quad \geq 4$ & & \\
Diabetes control & 10 & 25.6 \\
$\quad$ Good & 29 & 74.4 \\
$\quad$ Poor & & \\
\hline
\end{tabular}

\section{LEVELS OF TRACE ELEMENTS}

Tables 3 and 4 present the mean levels of trace elements in the hair and nails specimens of the sampled women according to their socio-demographic factors. Overall, the mean levels of all the six elements except selenium were higher in the hair specimens than in nails. The mean $\pm \mathrm{SD}$ levels of $\mathrm{Cr}, \mathrm{Zn}, \mathrm{Se}, \mathrm{Cu}, \mathrm{Fe}$ and $\mathrm{Mn}$ in hair specimens were $3.30 \pm 0.56,71.27 \pm 8.92,0.35 \pm 0.08,16.30 \pm 4.39$, $35.42 \pm 5.44$ and $1.92 \pm 0.13$, respectively. The mean levels of $\mathrm{Zn}$ and Se were significantly low among working participants compared to non-working $(p<0.05)$. Similarly, the mean levels of Fe and $\mathrm{Mn}$ among working participants were lower than the levels among non-working. However, the difference between the two groups was statistically not significant $(p>0.05)$. According to diabetes control, the mean level of $\mathrm{Cu}$ among those with poor control was significantly lower than the levels among the women with good control $(p<0.05)$. However, there were no significant differences in the mean levels of other elements in the hair specimens according to the age, number of children, educational level, employment status, diabetes control and duration of diabetes. On the other hand, the mean \pm $\mathrm{SD}$ levels of $\mathrm{Cr}, \mathrm{Zn}, \mathrm{Se}, \mathrm{Cu}, \mathrm{Fe}$, and $\mathrm{Mn}$ in nails specimens were $2.75 \pm 0.66,60.55 \pm 3.93,0.50 \pm 0.16,4.30 \pm 0.39$, $24.42 \pm 2.64$ and $0.29 \pm 0.03$, respectively. From Table 3, only the $\mathrm{Cu}$ level showed a significant difference between participating women according to diabetes control; those 
TABLE 3. Mean levels of trace elements in hair specimens of the subjects

\begin{tabular}{|c|c|c|c|c|c|c|}
\hline \multirow{2}{*}{ Variables } & \multicolumn{6}{|c|}{ Trace elements levels in hair $[$ mean $(\mu \mathrm{g} / \mathrm{g}) \pm \mathrm{SD}]$} \\
\hline & $\mathrm{Cr}$ & $\mathrm{Zn}$ & $\mathrm{Se}$ & $\mathrm{Cu}$ & $\mathrm{Fe}$ & $\mathrm{Mn}$ \\
\hline \multicolumn{7}{|l|}{$\operatorname{Age}^{a}$} \\
\hline $20-30$ & $2.92 \pm 0.48$ & $62.51 \pm 13.12$ & $0.28 \pm 0.05$ & $19.26 \pm 5.50$ & $49.55 \pm 6.31$ & $2.35 \pm 0.13$ \\
\hline $31-40$ & $3.67 \pm 0.74$ & $75.62 \pm 12.32$ & $0.39 \pm 0.08$ & $16.42 \pm 4.00$ & $22.18 \pm 6.62$ & $2.11 \pm 0.22$ \\
\hline $41-50$ & $3.16 \pm 0.14$ & $81.82 \pm 11.73$ & $0.31 \pm 0.06$ & $17.52 \pm 6.24$ & $35.52 \pm 6.72$ & $1.94 \pm 0.11$ \\
\hline $51-60$ & $3.19 \pm 0.52$ & $58.90 \pm 12.22$ & $0.47 \pm 0.05$ & $14.49 \pm 6.84$ & $49.66 \pm 4.62$ & $1.62 \pm 0.32$ \\
\hline \multicolumn{7}{|l|}{ Education status a } \\
\hline Primary school & $3.33 \pm 0.44$ & $83.92 \pm 14.41$ & $0.35 \pm 0.12$ & $19.77 \pm 2.21$ & $43.33 \pm 8.11$ & $2.36 \pm 0.45$ \\
\hline Secondary school & $3.35 \pm 0.54$ & $72.09 \pm 11.07$ & $0.39 \pm 0.21$ & $15.20 \pm 3.73$ & $34.38 \pm 7.12$ & $1.87 \pm 0.97$ \\
\hline Diploma/STPM & $2.97 \pm 0.23$ & $72.44 \pm 10.31$ & $0.29 \pm 0.08$ & $18.07 \pm 3.71$ & $29.90 \pm 6.53$ & $1.67 \pm 0.29$ \\
\hline \multicolumn{7}{|l|}{ Employment status ${ }^{\mathrm{b}}$} \\
\hline Working & $3.45 \pm 0.58$ & $64.98 \pm 11.10 *$ & $0.30 \pm 0.18^{*}$ & $17.38 \pm 4.83$ & $33.92 \pm 6.16$ & $1.81 \pm 0.14$ \\
\hline Not working & $3.12 \pm 0.49$ & $84.91 \pm 10.32$ & $0.42 \pm 0.15$ & $16.39 \pm 3.11$ & $41.22 \pm 5.12$ & $2.02 \pm 0.15$ \\
\hline \multicolumn{7}{|l|}{ Number of children ${ }^{b}$} \\
\hline$<4$ & $3.07 \pm 0.55$ & $76.87 \pm 10.24$ & $0.37 \pm 0.08$ & $15.49 \pm 5.17$ & $32.69 \pm 4.81$ & $2.03 \pm 0.28$ \\
\hline$\geq 4$ & $3.41 \pm 0.59$ & $68.67 \pm 9.34$ & $0.36 \pm 0.07$ & $18.15 \pm 6.30$ & $30.23 \pm 4.21$ & $1.83 \pm 0.07$ \\
\hline \multicolumn{7}{|l|}{ Diabetes control $^{\mathrm{b}}$} \\
\hline Good & $3.77 \pm 0.36$ & $63.48 \pm 10.35$ & $0.30 \pm 0.05$ & $20.41 \pm 4.20$ & $35.33 \pm 7.31$ & $1.66 \pm 0.06$ \\
\hline Poor & $3.07 \pm 0.34$ & $77.45 \pm 8.42$ & $0.38 \pm 0.08$ & $15.67 \pm 4.31 *$ & $36.63 \pm 5.72$ & $2.05 \pm 0.18$ \\
\hline \multicolumn{7}{|l|}{ Duration of diabetes ${ }^{b}$} \\
\hline$\leq 5$ years & $3.40 \pm 0.55$ & $70.30 \pm 12.32$ & $0.37 \pm 0.06$ & $17.68 \pm 5.22$ & $34.60 \pm 5.63$ & $1.88 \pm 0.34$ \\
\hline$>5$ years & $3.10 \pm 0.66$ & $72.94 \pm 13.68$ & $0.31 \pm 0.03$ & $15.03 \pm 4.01$ & $37.19 \pm 4.16$ & $1.97 \pm 0.28$ \\
\hline
\end{tabular}

${ }^{\text {a }}$ Differences were examined by one-way ANOVA; ${ }^{\mathrm{b}}$ differences were examined by independent $\mathrm{t}$-test

* Significant difference compared to poor control group $(p<0.05)$

TABLE 4. Mean levels of trace elements in nails specimens of the subjects

\begin{tabular}{|c|c|c|c|c|c|c|}
\hline \multirow{2}{*}{ Variables } & \multicolumn{6}{|c|}{ Trace elements levels in nails [mean $(\mu \mathrm{g} / \mathrm{g}) \pm \mathrm{SD}]$} \\
\hline & $\mathrm{Cr}$ & $\mathrm{Zn}$ & $\mathrm{Se}$ & $\mathrm{Cu}$ & $\mathrm{Fe}$ & $\mathrm{Mn}$ \\
\hline \multicolumn{7}{|l|}{ Age $^{a}$} \\
\hline 20-30 & $3.31 \pm 0.07$ & $68.34 \pm 5.22$ & $0.46 \pm 0.16$ & $3.42 \pm 0.37$ & $22.03 \pm 2.03$ & $0.20 \pm 0.04$ \\
\hline $31-40$ & $3.29 \pm 0.21$ & $58.94 \pm 4.52$ & $0.46 \pm 0.21$ & $3.93 \pm 0.64$ & $23.25 \pm 2.15$ & $0.37 \pm 0.04$ \\
\hline $41-50$ & $2.35 \pm 0.08$ & $59.46 \pm 9.60$ & $0.50 \pm 0.15$ & $4.40 \pm 0.40$ & $25.44 \pm 3.34$ & $0.28 \pm 0.03$ \\
\hline $51-60$ & $2.64 \pm 0.12$ & $60.85 \pm 4.96$ & $0.57 \pm 0.15$ & $5.09 \pm 0.79$ & $24.37 \pm 6.09$ & $0.27 \pm 0.06$ \\
\hline \multicolumn{7}{|l|}{ Education status a } \\
\hline Primary school & $2.62 \pm 0.71$ & $61.96 \pm 3.10$ & $0.44 \pm 0.07$ & $3.65 \pm 0.53$ & $26.17 \pm 5.68$ & $0.23 \pm 0.02$ \\
\hline Secondary school & $2.30 \pm 0.78$ & $60.00 \pm 1.74$ & $0.50 \pm 0.04$ & $4.38 \pm 0.39$ & $24.41 \pm 3.13$ & $0.31 \pm 0.03$ \\
\hline Diploma/STPM & $3.30 \pm 0.92$ & $61.03 \pm 2.76$ & $0.56 \pm 0.04$ & $5.13 \pm 0.63$ & $23.44 \pm 3.53$ & $0.28 \pm 0.06$ \\
\hline \multicolumn{7}{|l|}{ Employment status ${ }^{b}$} \\
\hline Working & $2.62 \pm 0.64$ & $59.58 \pm 4.90$ & $0.50 \pm 0.16$ & $4.56 \pm 0.14$ & $24.11 \pm 2.41$ & $0.33 \pm 0.03$ \\
\hline Not working & $2.79 \pm 0.67$ & $61.63 \pm 3.12$ & $0.50 \pm 0.17$ & $4.18 \pm 0.42$ & $24.70 \pm 3.80$ & $0.25 \pm 0.02$ \\
\hline \multicolumn{7}{|l|}{ Number of children ${ }^{b}$} \\
\hline$<4$ & $2.45 \pm 0.13$ & $59.50 \pm 2.61$ & $0.48 \pm 0.04$ & $4.10 \pm 0.35$ & $24.61 \pm 2.23$ & $0.29 \pm 0.03$ \\
\hline$\geq 4$ & $3.06 \pm 0.49$ & $61.12 \pm 2.07$ & $0.53 \pm 0.04$ & $4.69 \pm 0.50$ & $22.99 \pm 3.57$ & $0.28 \pm 0.04$ \\
\hline \multicolumn{7}{|l|}{ Diabetes control $^{\mathrm{b}}$} \\
\hline Good & $3.11 \pm 0.75$ & $60.13 \pm 3.42$ & $0.50 \pm 0.06$ & $3.35 \pm 0.46^{*}$ & $19.59 \pm 3.18$ & $0.24 \pm 0.03$ \\
\hline Poor & $2.56 \pm 0.51$ & $60.70 \pm 2.28$ & $0.51 \pm 0.03$ & $4.69 \pm 0.33$ & $26.09 \pm 2.59$ & $0.30 \pm 0.03$ \\
\hline \multicolumn{7}{|l|}{ Duration of diabetes ${ }^{b}$} \\
\hline$\leq 5$ years & $2.81 \pm 0.31$ & $60.71 \pm 9.12$ & $0.55 \pm 0.10$ & $4.55 \pm 0.62$ & $21.63 \pm 2.61$ & $0.30 \pm 0.03$ \\
\hline$>5$ years & $2.54 \pm 0.33$ & $58.23 \pm 5.46$ & $0.48 \pm 0.07$ & $4.84 \pm 0.65$ & $28.10 \pm 2.14$ & $0.32 \pm 0.04$ \\
\hline
\end{tabular}

a differences were examined by one-way ANOVA; ${ }^{b}$ differences were examined by independent $t$-test

significant difference compared to poor control group $(p<0.05)$ 
with poor control had lower $\mathrm{Cu}$ levels $(p<0.05)$. However, there were no significant differences in the mean levels of other elements in the nails specimens according to age, number of children, educational level, employment status, diabetes control and duration of diabetes.

Pearson's correlation coefficients for the levels of trace elements in the hair and nails specimens are shown in Table 5. There were significant and positive correlations between $\mathrm{Cr} / \mathrm{Cu}, \mathrm{Zn} / \mathrm{Mn}$ and $\mathrm{Se} / \mathrm{Mn}$ levels in the hair specimens $(r=0.63,0.43$ and 0.32 , respectively). Similarly, there were significant positive correlations between $\mathrm{Cr} / \mathrm{Zn}, \mathrm{Fe} / \mathrm{Mn}$ and $\mathrm{Zn} / \mathrm{Fe}(\mathrm{r}=0.31,0.47$ and 0.30$)$. On the other hand, there was a significant negative correlation between Se and $\mathrm{Mn}$ $(r=-0.30)$. The correlation between trace elements in hair and nails specimens was investigated and found to be not significant $(p>0.05)$.

\section{DISCUSSION}

The prevalence of diabetes mellitus is increasing in developing countries, including Malaysia, with a growing incidence of type 2 DM which accounts for about $90 \%$ of all cases. Alteration in the status of trace elements in diabetic patients has been reported with elements deficiencies as an evident disturbance of trace elements in diabetes (Khalid et al. 2014). Data on trace elements status among Malaysians is still lacking. Few studies have been done in Asia to evaluate the status of certain trace elements among diabetes mellitus patients (Alwan \& Hamood 2017; Atieh et al. 2015; Praveeena et al. 2013; Skalnaya \& Demidov 2007; Sukumar \& Subramanian 2007; Tasneem et al. 2008; Yerlikaya et al. 2013). Moreover, data on the status of trace elements in the nails of diabetic patients are still limited.
In the present study, the levels of six elements were evaluated in the hair and nails specimens of Malay women with type $2 \mathrm{DM}$. The levels of these elements, except Se, were higher in the hair samples compared to the nails. The findings showed that $\mathrm{Cr}$ levels in nails and hair were more than the values reported in India and Pakistan (Sukumar \& Subramanian 2007; Tasneem et al. 2008). Taking into consideration the influence of many factors like occupation, dietary habits, climate, geographical location, parameters of trace element exchange may alter between populations (Skalnaya \& Skalny 2018). The higher values of Cr among Malay women could be attributed to the consumption of some foods such as nuts, mushrooms and oysters which are essential in the Malaysian cuisine. These kinds of foods are rich in $\mathrm{Cr}$ (Gibson 1998). The ingestion of supplements and traditional medicine is a possible cause since some respondents mentioned using these compounds.

A previous local study reported the availability of $\mathrm{Cr}$ besides 28 other elements in the medicinal herbs commonly used in Malaysia (Sarmani et al. 1999). Additionally, a recent report in Malaysia found that $52.4 \%$ of diabetic patients with type 2 DM use dietary supplements (Tan et al. 2015). Variation in $\mathrm{Cr}$ and other trace elements measurements due to the instruments, sample collection, washing procedures, age and gender should also be considered.

Regarding the levels of $\mathrm{Zn}$ in hair and nails, our findings showed lower levels among Malay women compared to previous studies abroad. This might be explained by the variation in environment and food consumption (Tasneem et al. 2008). Malaysians eat less red meat which is the major source of bioavailable $\mathrm{Zn}$ (Tran 2008). The mean level of $\mathrm{Cu}$ in the hair samples reported by

TABLE 5. Correlation analysis of trace element in hair and nails specimens of the subjects

\begin{tabular}{lcccc}
\hline \multirow{2}{*}{$\begin{array}{l}\text { Trace element } \\
\text { in pairs }\end{array}$} & \multicolumn{2}{c}{ Hair specimens } & \multicolumn{2}{c}{ Nails specimens } \\
\cline { 2 - 5 } & $\mathrm{r}^{\mathrm{a}}$ & $\mathrm{P}$ & $\mathrm{r}^{\mathrm{a}}$ & $\mathrm{P}$ \\
\hline $\mathrm{Cr} / \mathrm{Zn}$ & 0.016 & 0.461 & $0.316^{*}$ & 0.025 \\
$\mathrm{Cr} / \mathrm{Se}$ & 0.191 & 0.122 & 0.199 & 0.112 \\
$\mathrm{Cr} / \mathrm{Cu}$ & $0.550^{* *}$ & 0.001 & -0.024 & 0.441 \\
$\mathrm{Cr} / \mathrm{Fe}$ & 0.208 & 0.154 & -0.008 & 0.481 \\
$\mathrm{Cr} / \mathrm{Mn}$ & -0.148 & 0.185 & 0.149 & 0.183 \\
$\mathrm{Zn} / \mathrm{Se}$ & 0.184 & 0.131 & 0.082 & 0.309 \\
$\mathrm{Zn} / \mathrm{Cu}$ & 0.020 & 0.452 & 0.107 & 0.259 \\
$\mathrm{Zn} / \mathrm{Fe}$ & 0.120 & 0.280 & $0.307 *$ & 0.029 \\
$\mathrm{Zn} / \mathrm{Mn}$ & $0.467 * *$ & 0.001 & 0.066 & 0.345 \\
$\mathrm{Se} / \mathrm{Cu}$ & -0.168 & 0.153 & 0.153 & 0.176 \\
$\mathrm{Se} / \mathrm{Fe}$ & 0.189 & 0.177 & -0.258 & 0.056 \\
$\mathrm{Se} / \mathrm{Mn}$ & $0.382^{* *}$ & 0.008 & $-0.309 *$ & 0.028 \\
$\mathrm{Cu} / \mathrm{Fe}$ & -0.014 & 0.474 & 0.161 & 0.164 \\
$\mathrm{Cu} / \mathrm{Mn}$ & 0.060 & 0.359 & 0.163 & 0.160 \\
$\mathrm{Fe} / \mathrm{Mn}$ & 0.113 & 0.291 & $0.474^{* *}$ & 0.001 \\
\hline
\end{tabular}

a Pearson's correlation coefficient

* Significant at $p<0.01 ; * *$ Significant at $p<0.001$ 
the present study was higher than the mean level reported among Pakistani patients (Tasneem et al. 2008). However, Sukumar and Sumramanian (2007) reported a higher level among Indian patients. Our study found no significant difference in the levels of trace elements according to age groups. This finding supports previous reports from India and Bangladesh (Hussain et al. 2009; Sukumar \& Subramanian 2007).

In contrast, Tasneem et al. (2008) reported that the levels of $\mathrm{Zn}$ and $\mathrm{Cr}$ in blood and hair scalp were low in the older diabetic subjects compared to the younger patients. This could be attributed to the lower absorption of nutrients through the gut in the elderly subjects. Also, elderly people eat less and due to the difficulty of leaving the house, could be more likely to eat long-life food, low in $\mathrm{Zn}$ and some nutrients (Garg et al. 2005). Moreover, Sánchez et al. (2010) reported a positive correlation between plasma Se and age. It was postulated that there is a tendency for Se levels to increase among the population with a stronger preference for a traditional diet consumed mainly by elderly people more than younger groups (Sánchez et al. 2010).

The present study found no significant differences in the levels of trace elements among the subjects according to their educational level and number of children. All subjects had primary school education as a minimum, which means all patients have a basic degree of education. Persell et al. (2004) concluded that knowledgeable patients were more likely to perform self-management activities.

Some studies showed that serum $\mathrm{Zn}$ levels decreased in diabetic patients (Bolajok et al. 2017; Praveeena et al. 2013). The present study showed significant differences in the levels of $\mathrm{Zn}, \mathrm{Se}$, and $\mathrm{Cu}$ according to the employment status of subjects. The levels of $\mathrm{Zn}$ and Se in the hair specimens were low among working compared to nonworking women, possibly due to the occupational stress. Stress has been reported to affect the metabolism of $\mathrm{Zn}$ resulting in a reduction in plasma zinc levels and enhancing $\mathrm{Zn}$ loss in the urine (Boosalis et al. 1991). Moreover, stress led to an internal redistribution of $\mathrm{Zn}$ to other organs such as the liver and loss from other tissues such as the intestine and pancreas (Heyland et al. 2008; McClain et al. 1993). Interestingly, a recent meta-analysis reported possible zinc deficiencies in type 2 diabetic individuals (Namrata et al. 2018).

Previous studies concluded that the exposure to chronic psychological stressors such as job pressures or psychological stress caused by the death of a spouse or a financial crisis is associated with higher risk of developing diabetes in middle age and contribute to the global burden of the disease (Wellen \& Hotamisligil 2005: WHO 2001). The lower levels of Se in the hair of the working group may be attributed to the increased need for selenium due to the exposure to the polluted environment in some workplaces.

A previous study showed that plasma selenium levels among oil refinery workers were significantly lower than their levels among non-industrial groups. Furthermore, water quality, hair treatment and cosmetics such as some shampoo formulated with selenium sulfide might also contribute to the variation of the Se levels (LeBlanc et al. 1999). Interestingly, our findings variation in the levels of $\mathrm{Cu}$ in the hair and nails specimens according to the employment status of the subjects. We found that the level of $\mathrm{Cu}$ in the hair specimens was significantly lower among women with good or satisfactory diabetes control compared to those with poor diabetes control.

In contrast, the level of $\mathrm{Cu}$ in the nail's specimens of women with poor diabetes control was significantly higher than in those with good diabetes control. Previous studies reported that concentrations of trace elements were not related to the degree of glucose control as determined by correlation analysis between $\mathrm{HbA1c}$ and elements levels in the blood fractions (Ekmekcioglu et al. 2001; Rohn et al. 1993). We believe that the result using hair specimens was more acceptable as the lower $\mathrm{Cu}$ in poor diabetes control group associated with higher $\mathrm{Zn}$ levels. Rowin and Lewis (2005) and Willis et al. (2005) reported that Zn could replace $\mathrm{Cu}$ in people using supplements or minerals containing excess $\mathrm{Zn}$. Moreover, elements levels in nails are mainly influenced by place of residence whereas hair elements are influenced by seasonal variations (Wilhelm et al. 1991). Glycated haemoglobin (HbA1c) estimates blood glucose concentration for the previous two to three months, and nails and hair samples showed elements concentration for the long-term (Jun et al. 1990). Thus, using HbA1c as an indicator of diabetes control to correlate or to compare between trace elements in hair and nails might not be useful unless only one or two proximal centimetres of hair are used. The increase in $\mathrm{Cu}$ levels in diabetic patients might be attributed to the hyperglycaemia that may stimulate glycation to release $\mathrm{Cu}$ ions from the copper contains enzymes and proteins such as superoxide dismutase (SOD) and ceruloplasmin (CP) (Abou-Seif \& Youssef 2004).

In the present study, the duration of diabetes did not influence the trace elements levels. This was consistent with previous studies (Hussain et al. 2009; Zargar et al. 1998). Additionally, a recent report showed that as the duration of DM increases, the Cr level was decreased, whereas no statistically significant change was shown in the levels of Mn, Zn, Fe and Cu (Gahlot \& Bhatnagar 2018). However, Nsonwu et al. (2006) reported that serum and urine trace elements concentrations varied significantly with the increasing duration of diabetes urging that diabetes alters the metabolism of zinc, magnesium, selenium and chromium by decreasing their serum concentration and increasing their urinary excretion (Nsonwu et al. 2006).

Our findings showed significant correlations between the elements taking into consideration the type of specimen. These findings support previous studies (Ömer et al. 1993; Sukumar \& Subramanian 2007). Watts (1990) urged that the relationship between nutrients is complex, especially between trace elements. Thus, an affected element will affect at least two minerals, and each of them will also affect two others. Moreover, some elements act as synergism or antagonism to others.

Although this study is the first, to the best of our knowledge, to evaluate the status of trace elements among 
diabetic patients in Malaysia, some limitations in the study design (cross-sectional) should be considered. These include its small sample size and absence of control due to limited study time, lack of serum samples and urine samples, lack of dietary habits history, data on the taking of supplements was not available due to the difficulty to recall or to know the contents of the elements contained in the supplements.

In conclusion, the findings of this study indicate that there were differences in the levels of trace elements between hair and nails among Malay women with type 2 diabetes mellitus. However, socio-demographic factors could influence the levels of certain trace elements. To better understand the role of these trace elements in diabetes, more studies are needed. The results could also be supported by a more significant number of patients and by using blood and urine samples.

\section{ACKNOWLEDGEMENTS}

The authors would like to acknowledge the participants and the director and staff of the clinics (Bangi, Kajang \& Beranang) for their assistance. We acknowledge Mr. Awang $\mathrm{Ku}$ Jalaudin bin Awang Besar and Mr. Mohd Jamil Mohd Rafaai for their assistance in setting the instruments and apparatuses needed in order to conduct this research. We also acknowledge Universiti Kebangsaan Malaysia for its financial support.

\section{REFERENCES}

Abou-Seif, Mosaad,A. \& Abd-Allah, Youssef. 2004. Evaluation of some biochemical changes in diabetic patients. Clinica Chimica Acta 346(2): 161-170.

Altamura, S., Stefan, K., Schmidt, J., Müdder, K., da Silva, A.R., Nawroth, P. \& Muckenthaler, M.U. 2017. Uncoupled iron homeostasis in type 2 diabetes mellitus. Journal of Molecular Medicine 95(12): 1387-1398

Alwan, I.F. \& Hamood, A.M. 2017. Serum trace elements in patients with Type 2 diabetes mellitus. In Proceeding of 1st National Conference of Science and Art University of Babylon Mesopotemia Environmental Journal, Special Issue C. pp. 16-23

Atieh Makhlough, Marjan Makhlough, Mohammad Shokrzadeh, Mozhdeh Mohammadian, Omid Sedighi \& Mansooreh Faghihan. 2015. Comparing the levels of trace elements in patients with diabetic nephropathy and healthy individuals. Nephro-Urology Monthly 7(4): e28576.

Batista, B.L., Rodrigues, J.L., Nunes, J.A., Tormen, L., Curtius, A.J. \& Barbosa, F. 2008. Simultaneous determination of $\mathrm{Cd}, \mathrm{Cu}, \mathrm{Mn}, \mathrm{Ni}, \mathrm{Pb}$ and $\mathrm{Zn}$ in nail samples by inductively coupled plasma mass spectrometry (ICP-MS) after tetramethylammonium hydroxide solubilisation at room temperature: Comparison with ETAAS. Talanta 76(3): 575-579.

Bolajoko, E.B., Akinosun, O.M., Anetor, J. \& Mossanda, K.S. 2017. Relationship between selected micronutrient deficiencies and oxidative stress biomarkers in diabetes mellitus patients with foot ulcers in Ibadan, Nigeria. Turkish Journal of Medical Sciences 47(4): 1117-1123.
Boosalis, M.G., Solem, L.D., Cerra, F.B., Konstantinides, F., Ahrenholz, D.H., McCall, J.T. \& McClain, C.J. 1991. Increased urinary zinc excretion after thermal injury. The Journal of Laboratory and Clinical Medicine 118(6): 538545.

Burlet, E. \& Jain, S.K. 2013. Manganese supplementation reduces high glucose-induced monocyte adhesion to endothelial cells and endothelial dysfunction in Zucker diabetic fatty rats. Journal of Biological Chemistry 288(9): 6409-6416.

De Vega, R.Z., Fernández-Sánchez, M.L., Fernández, J.C., Menéndez, F.V.Á. \& Sanz-Medel, A. 2016. Selenium levels and glutathione peroxidase activity in the plasma of patients with type II diabetes mellitus. Journal of Trace Elements in Medicine and Biology 37: 44-49.

Ekmekcioglu, C., Prohaska, C., Pomazal, K., Steffan, I., Schernthaner, G. \& Wolfgang Marktl. 2001. Concentrations of seven trace elements in different hematological matrices in patients with type 2 diabetes as compared to healthy controls Biological Trace Element Research 79(3): 205-219.

Fatma Hussain, Mohammad Arif Maan, Munir Ahmed Sheikh, Haq Nawaz \& Amer Jamil. 2009. Trace elements status in type 2 diabetes. Bangladesh Journal of Medical Science 8(3): 52.

Flores, C.R., Puga, M.P., Wrobel, K., Sevilla, M.E.G. \& Wrobel, K. 2011. Trace elements status in diabetes mellitus type 2: Possible role of the interaction between molybdenum and copper in the progress of typical complications. Diabetes Research and Clinical Practice 91(3): 333-341.

Gahlot, N.K. \& Bhatnagar, V. 2018. A study of trace elements in serum of diabetic patients. IOSR Journal of Dental and Medical Sciences 17(2): 4-7.

Garg, A.N., Kumar, A., Maheshwari, G. \& Sharma, S. 2005. Isotope dilution analysis for the determination of zinc in blood samples of diabetic patients. Journal of Radioanalytical and Nuclear Chemistry 263(1): 39-43.

Gibson, R. 1998. Ultratrace elements. In Essentials of Human Nutrition, edited by Mann, J. \& Truswell, S. New York: Oxford University Press. pp. 176-178.

Heyland, D.K., Jones, N., Cvijanovich, N.Z. \& Wong, H. 2008. Zinc supplementation in critically ill patients: A key pharmaconutrient? Journal of Parenteral \& Enteral Nutrition 32(5): 509-519.

Jun Yoshinaga, Hideki Imai, Minato Nakazawa, Tsuguyoshi Suzuki \& Masatoshi Morita. 1990. Lack of significantly positive correlations between elemental concentrations in hair and in organs. Science of the Total Environment 99(12): 125-135.

Khalid Siddiqui, Nahla Bawazeer \& Salini Scaria Joy. 2014. Variation in macro and trace elements in progression of type 2 diabetes. The Scientific World Journal 2014: 461591.

LeBlanc, A., Dumas, P. \& Lefebvre, L. 1999. Trace element content of commercial shampoos: Impact on trace element levels in hair. Science of the Total Environment 229(1): 121-124.

Lee, Soh-Hyun, Jouihan, H.A., Cooksey, R.C., Jones, D., Kim, H.J., Winge, D.R. \& McClain, D.A. 2013. Manganese supplementation protects against diet-induced diabetes in wild type mice by enhancing insulin secretion. Endocrinology 154(3): 1029-1038.

Lowe, J., da-Silva, R.T. \& Souza, E.H. 2017. Dissecting copper homeostasis in diabetes mellitus. IUBMB Life 69(4): 255-262.

McClain, C.J., McClain, M.L., Boosalis, M.G. \& Hennig, B. 1993. Zinc and the stress response. Scandinavian Journal of Work Environment \& Health 19(Suppl 1): 132-133. 
Miekeley, N., Dias Carneiro, M.T.W. \& da Silveira, C.L.P.1998. How reliable are human hair reference intervals for trace elements? Science of the Total Environment 218(1): 9-17.

Ministry of Health Malaysia. 2015. National Health and Morbidity Survey.

Namrata Sanjeevi, Freeland-Graves, J., Beretvas, S.N. \& Sachdev, P.K. 2018. Trace element status in type 2 diabetes: A meta-analysis. Journal of Clinical \& Diagnostic Research 12(5): OE01- OE08.

Nsonwu, A.C., Opera Usoro, C.A., Etukudo, M.H. \& Usoro, I.N 2006. Influence of age, gender and duration of diabetes on serum and urine levels of zinc, magnesium, selenium and chromium in type 2 diabetics in Calabar, Nigeria. Turkish Journal of Biochemistry 31(3): 107-114.

Ömer Akyol, Mustafa Kavutçu, Orhan Canbolat, Bünyamin Ișik \& İlker Durak. 1993. A study on the relationships between some of the trace element levels of hair, nail, serum and urine in healthy subjects. Turkiye Klinikleri Journal of Case Reports 11(2): 75-81.

Persell, S.D., Keating, N.L., Landrum, M.B., Landon, B.E., Ayanian, J.Z. \& Guadagnoli, E. 2004. Relationship of diabetes-specific knowledge to self-management activities, ambulatory preventive care, and metabolic outcomes. Preventive Medicine 39(4): 746-752.

Praveeena, S., PaSula, S. \& Sameera, K. 2013. Trace elements in diabetes mellitus. Journal of Clinical \& Diagnostic Research 7(9): 1863-1865.

Qiu, Q., Zhang, F., Zhu, W., Wu, J. \& Liang, M. 2017. Copper in diabetes mellitus: A meta-analysis and systematic review of plasma and serum studies. Biological Trace Element Research 177(1): 53-63.

Rampal, S., Rampal, L., Rahmat, R., Azhar Md Zain, Yee Guan Yap, Mafauzy Mohamed \& Mohamad Taha. 2010. Variation in the prevalence, awareness, and control of diabetes in a multiethnic population: A nationwide population study in Malaysia. Asia Pacific Journal of Public Health 22(2): 194-202.

Rayman, M.P. 2000. The importance of selenium to human health. The Lancet 356(9225): 233-241.

Rhee, E-J. 2015. Diabetes in Asians. Endocrinology and Metabolism 30(3): 263-269.

Rohn, R.D., Pleban, P. \& Jenkins. L.L. 1993. Magnesium, zinc and copper in plasma and blood cellular components in children with IDDM. Clinica Chimica Acta 215(1): 21-28.

Rowin, J. \& Lewis, S.L. 2005. Copper deficiency myeloneuropathy and pancytopenia secondary to overuse of zinc supplementation. Journal of Neurology, Neurosurgery \& Psychiatry 76(5): 750-751.

Sánchez, C., López-Jurado, M., Pilar, A. \& Llopis, J. 2010. Plasma levels of copper, manganese and selenium in an adult population in southern Spain: Influence of age, obesity and lifestyle factors. Science of the Total Environment 408(5): 1014-1020.

Sarmani, S.B., Abugassa, I., Hamzah, A. \& Yahya, M.D. 1999. Elemental analysis of herbal preparations for traditional medicines by neutron activation analysis with the k0 standardization method. Biological Trace Element Research 71(1): 365-376.

Skalnaya, M.G. \& Skalny, A.V. 2018. Essential Trace Elements in Human Health: A Physician's View. Tomsk, Lenin Ave.: Publishing House of Tomsk State University. pp. 36-224.

Skalnaya, M.G. \& Demidov, V.A. 2007. Hair trace element contents in women with obesity and type 2 diabetes. Journal of Trace Elements in Medicine \& Biology 21: 59-61.
Sukumar, A. \& Subramanian, R. 2007. Relative element levels in the paired samples of scalp hair and fingernails of patients from New Delhi. Science of the Total Environment 372(2-3): 474-479.

Talbot, J. \& Weiss, A. 1994. Laboratory Methods for ICP-MS Analysis of Trace Metals in Precipitation. East Hazelwood, Champaign, IL: Hazardous Materials Lab, Hazardous Waste Research and Information Center.

Tan Mun Chieng, Ooi Chuan Ng, Teck Wee Wong, Anthony Joseph, Abdul Rahman Hejar \& Abdul Aziz Rushdan. 2015. Dietary compliance, dietary supplementation and traditional remedy usage of type 2 diabetic patients with and without cardiovascular disease. Clinical Nutrition Research 4(1): 18-31.

Tasneem Kazi, Hassan Imran Afridi, Naveed Kazi, Mohammad Khan Jamali, Mohammad Bilal Arain, Nussarat Jalbani \& Ghulam Abbas Kandhro. 2008. Copper, chromium, manganese, iron, nickel, and zinc levels in biological samples of diabetes mellitus patients. Biological Trace Element Research 122(1): 1-18.

Tran, C.D. 2008. Advances of zinc in health research. In Micronutrient and Health Research, edited by Yoshida, T. New York: Nova Science Publishers, Inc. pp. 23-70.

Unjiati, Bambang Wirjatmadi \& Merryana Adriani. 2015. Chromium and zinc level of patients with type 2 diabetes and non-diabetes. Biochemistry \& Physiology doi:10.4172/21689652.S5-010.

Watts, D.L. 1990. Nutrient interrelationships: Minerals, vitamins, endocrines. Journal of Orthomolecular Medicine 5(1): 11-19.

Wellen, K.E. \& Hotamisligil, G.S. 2005. Inflammation, stress, and diabetes. Journal of Clinical Investigation 115(5): 1111-1119.

Wilhelm, M., Hafner, D., Lombeck, I. \& Ohnosorge, F.K. 1991. Monitoring of cadmium, copper, lead and zinc status in young children using toenails: Comparison with scalp hair. Science of the Total Environment 103(2-3): 199-207.

Willis, M.S., Monaghan, S.A., Miller, M.L., McKenna, R.W., Perkins, W.D., Levinson, B.S., Vikas Bhushan. \& Kroft, S.H 2005.Zinc-induced copper deficiency: A report of three cases initially recognized on bone marrow examination. American Journal of Clinical Pathology 123(1): 125-131.

Wolfgang, M. 2017. Zinc in pancreatic islet biology, insulin sensitivity, and diabetes. Preventive Nutrition and Food Science 22(1): 1-8

World Health Organization 2016. Global Report on Diabetes. Geneva: World Health Organization.

World Health Organization 2001. The World Health Report 2001: Mental Health: New Understanding, New Hope. Geneva: World Health Organization.

Yerlikaya, F.H., Aysun Toker \& Alpay Arıbaş. 2013. Serum trace elements in obese women with or without diabetes. The Indian Journal of Medical Research 137(2): 339-345.

Zargar, A.H., Shah, N.A., Masoodi, S.R., Laway, B.A., Dar, F.A., Khan, A.R., Sofi, F.A. \& Wani, A.I. 1998. Copper, zinc, and magnesium levels in non-insulin dependent diabetes mellitus. Postgraduate Medical Journal 74(877): 665-668.

Mohammed Nashiry*, Ismarulyusda Ishak, Jamaludin Mohamed, Siti Balkis Budin \& Sazlina Kamaralzaman

Department of Biomedical Sciences

Faculty of Health Sciences

Universiti Kebangsaan Malaysia 
Jalan Raja Muda Abdul Aziz

50300 Kuala Lumpur, Federal Territory

Malaysia

Mohd Fairulnizal M.N.

Nutrition Unit

Cardiovascular, Diabetes, and Nutrition Research Centre

Institute of Medical Research

50588 Kuala Lumpur, Federal Territory

Malaysia
Hesham M. Al-Mekhlafi

Medical Research Centre

Jazan University

Kingdom of Saudi Arabia

*Corresponding author; email: ismarul@ukm.edu.my

Received: 20 June 2018

Accepted: 3 October 2018 